\title{
Integrated Nutrient Management on Growth and Productivity of Rapeseed-mustard Cultivars
}

\author{
P. K. Saha ${ }^{1}$, G. C. Malik ${ }^{2}$, P. Bhattacharyya ${ }^{1}$ and M. Banerjee ${ }^{2^{*}}$
}

${ }^{1}$ Pulses and Oilseeds Research Station, Berhampore, Murshidabad, West Bengal (742 101), India

${ }^{2}$ Dept. of ASEPAN, Institute of Agriculture, Visva-Bharati, Sriniketan, West Bengal (731 236), India

${ }^{3}$ Dept. of Agriculture, Govt. of West Bengal (700 001), India

\section{Article History}

Manuscript No. AR845

Received in $12^{\text {th }}$ July, 2014

Received in revised form $18^{\text {th }}$ March, 2015

Accepted in final form $5^{\text {th }}$ April, 2015

\section{Correspondence to}

*E-mail: mahua.banerjee@visva-bharati.ac.in

\section{Keywords}

Nutrient management, variety, rapeseedmustard, seed yield

\begin{abstract}
To find out the efficacy of different integrated nutrient management a field experiment was conducted at Pulses and Oilseeds Research Station, Berhampore, W.B, during Rabi season of 2009-10 and 2010-11 on Rapeseed-Mustard. The experiment was laid out in split plot design and replicated thrice with three varieties viz., $\mathrm{V}_{1}$, Binoy (B -9); $\mathrm{V}_{2}$, Sarama; $\mathrm{V}_{3}$, Kalyan(WBBN-1) in main plots and five fertility management $\left\{\mathrm{F}_{1}=100\right.$ 50-50-30 N- $\mathrm{P}_{2} \mathrm{O}_{5}-\mathrm{K}_{2} \mathrm{O}, \mathrm{S} \mathrm{kg} \mathrm{ha}{ }^{-1}$ (recommended), $\mathrm{F}_{2}=\mathrm{RD}+5 \mathrm{t} \mathrm{FYM} \mathrm{ha}{ }^{-1}, \mathrm{~F}_{3}=\mathrm{RD}+5 \mathrm{t}$ $\mathrm{FYM}+$ Azotobacter, $\mathrm{F}_{4}=\mathrm{RD}+5 \mathrm{t} \mathrm{FYM}+\mathrm{PSB} ., \mathrm{F}_{5}=\mathrm{RD}+5 \mathrm{tFYM}+\mathrm{PSB} .+$ Azotobacter $\}$ as sub-plot treatments. The highest plant height $(\mathrm{cm})$, number of primary branches plant ${ }^{-1}$ and dry matter accumulation (g) were achieved in the crops receiving a combinations of fertility treatment with the recommended dose of chemical fertilizers along with FYM, Azotobacter and PSB during both the years. Significant increase in yield was found in Sarama variety followed by the variety Binoy and Kalyan. The application of $\mathrm{RD}+2$ t FYM+PSB+Azotobacter resulted significant increase in Seed yield, biological yield and oil percentage in all Rapeseed-Mustard varieties. The highest net return of ₹ 22106.56 and ₹ 23262.11 ha $^{-1}$ respectively during the two years of the experimentation were recorded from the rapeseed-mustard crop raised with the recommended dose of chemical fertilizers, FYM, Azotobacter and PSB together. The benefit cost ratio also indicated that the treatment R.D +2 t FYM+PSB + Azotobacter was more remunerative.
\end{abstract}

\section{Introduction}

Rapeseed-Mustard are the third important oilseed crop in the world after soybean (Glysine max) and palm (Elaeis guineensis) oil. In India, it is the second most important edible oilseed after groundnut among nine annual oilseed crops grown. It is one of the best edible oils available, having lowest amount of saturated fats as compared to other vegetable oils and provides both essential fatty acids and also the animal feed through oilfree meal rich in protein having well-balanced aminoacid and equally having the potential for purpose of biofuel (Anjum et al., 2012; Shekhawat et al., 2012; Cardole et al., 2003.). To meet the ever increasing demand of oilseeds, we require stepping up average productivity of oilseeds crops from present level of productions (Mohiuddin et al., 2011). The estimated area, production and yield of rapeseed-mustard in the world was $34.19 \mathrm{mha}, 63.09 \mathrm{mt}$ and $1,850 \mathrm{~kg} \mathrm{ha}^{-1}$, respectively, during 2013-14. Globally, India account for $19.29 \%$ and $11.127 \%$ of the total acreage and production (Economic Survey, 2014-
15).

The Rapeseed-Mustard group includes brown sarson, raya and toria crops. Indian mustard (Brassica juncea (L.) Czernj. and Czern) is predominantly cultivated in Rajasthan, UP, Haryana, Madhya Pradesh and Gujrat. It is also grown under some nontraditional areas of south India including Karnataka, Tamil Nadu and Andhra Pradesh. The crop can also be raised well under both irrigated and rainfed conditions. Yellow sarson (B. rapa var. trilocularis) is cultivated in Assam, Bihar, Orissa and West Bengal as rabi crop. Gobhi sarson (B. napus I. ssp. oleferia DC. Var. annua L.) and karan rai (Brassica carinata) are the new emerging oilseed crops having limited area of cultivation. Rapeseed-Mustard are cultivated in most temperate climates and also grown in certain tropical and subtropical regions as a cold weather crop. Since, there is a vast variability in the climate and edaphic conditions in the mustard growing areas of India, the selection of appropriate cultivars is important as it helps in increasing the productivity (Shekhawat et al., 2012). 
Indiscriminate use of chemical fertilizers for the supply of major nutrients and declining use of secondary nutrients and organic sources of inputs over time led to the deficiency of secondary and micronutrients (De et al., 2014). Through the approach of integrated nutrient management, it is important to exploit the potential of organic manures, composts, crop residues, agricultural wastes, biofertilizers and synergistic effect with chemical fertilizers for increasing balanced nutrient supply and their use efficiency for increasing productivity, sustainability of agriculture, and improving soil health and environment safety. Judicious combination of FYM, biofertilizers and chemical fertilizers facilitate profitable and sustainable production (Singh and Sinsinwar, 2006. and De et al., 2009). The bio-fertilizers have an important role to play in improving the nutrient's supplies (by way of nitrogen fixation or solubilization of phosphorus), their availability in crop production; production of growth hormones and antifungal substances favorably effect crop growth (Tripathi et al., 2010. De and Sinha., 2011. and AICRP-RM. 2005). The introduction of leguminous crops in the rotational and intercropping sequence and use of bacterial and algal cultures play an important role in increasing the nutrient use efficiency (Prasad et al., 1992; Maiti et al., 2005). Therefore, the present study was carried out to develop suitable package for sustainable productivity of rapeseed-mustard in Gangetic Alluvial Zones of West Bengal.

\section{Materials and Methods}

The field experiment was conducted during Rabi and Prekharif seasons of 2009-2010 and 2010-11 at Pulses \& Oilseeds Research Station, Berhampore, Mursidabad, West Bengal $\left(24^{\circ} 50^{\prime} \mathrm{N}\right.$ latitude and $88^{\circ} 13^{\prime} \mathrm{E}$ longitude with an altitude of 9.75 masl. The experimental site falls under subtropical humid climate. The average annual rainfall was $1450 \mathrm{~mm}$, $75 \%$ of which was received during Monsoon months of June to September. The temperature begins to rise from the end of February reaching maximum towards April-May. The relative humidity remains high during June-October. The soil of the experimental field was moderately well drained typical Gangetic alluvial (Entisol) soil with sandy clay loam texture having $6.6 \mathrm{pH}, 0.56 \%$ organic carbon, 160:16:124:8.1 $\mathrm{kg} \mathrm{ha}^{-1}$ available N-P-K-S, good water holding capacity,. The experiment was laid out in a split plot design having three varieties- $\mathrm{V}_{1}: \mathrm{B}-9$ (Binoy); $\mathrm{V}_{2}: \mathrm{RW}-85-59$ (Sarama); $\mathrm{V}_{3}:$ WBBN-1 (Kalyan) as main plots and five nutrient management treatments $\mathrm{F}_{1}=100: 50: 50: 30\left(\mathrm{~N}: \mathrm{P}_{2} \mathrm{O}_{5}-\mathrm{K}_{2} \mathrm{O}\right), \mathrm{S} \mathrm{kg} \mathrm{ha}^{-1}$ (recommended), $\mathrm{F}_{2}=\mathrm{RD}+5 \mathrm{tFYM} \mathrm{ha}^{-1}, \mathrm{~F}_{3}=\mathrm{RD}+5 \mathrm{tFYM}+$ Azotobacter, $\mathrm{F}_{4}=\mathrm{RD}+5 \mathrm{t}$ FYM+PSB., $\mathrm{F}_{5}=\mathrm{RD}+5$ t FYM+PSB+Azotobacter as sub-plot treatments and were replicated thrice. During the two years of experimentation, Rapeseed-mustard was sown in 2.11.2009 and 1.11.2010 respectively. The N, K, P and S were supplied through Urea, Muriate of Potash, Single Super Phosphate and elemental sulphur respectively and well decomposed farm yard manure(FYM) was applied as per treatment. The half part of the recommended dose of nitrogenous fertilizer and full dose of $\mathrm{P}_{2} \mathrm{O}_{5}, \mathrm{~K}_{2} \mathrm{O}$ and $\mathrm{S}$ were applied as basal and rest half part of the recommended dose of nitrogenous fertilizer was applied as first top dressing (30 DAS). The Rapeseed-mustard were harvested between first week to third week of February. The oil content was estimated by Soxhlet apparatus (utilized for oil extraction and petroleum ether used as solvent), the volume of oil content concentrated by using water bath and the concentrated oil estimated by weight basis.

\section{Results and Discussion}

\subsection{Growth}

The plant height $(\mathrm{cm})$, number of primary branches per plant, dry matter accumulation (g), of rapeseed-mustard at various stages of crop growth was significantly influenced by different nutrient management practices and also by different varieties (Table 1). The highest plant height, number of primary branches per plant, dry matter accumulation (g), were achieved in the crops receiving a combination of fertility treatment with the recommended dose of chemical fertilizers along with FYM, Azotobacter and PSB during both the years and were widely followed by the crops under fertility treatment the recommended dose of chemical fertilizers along with FYM and Azotobacter. In comparison between these two treatments, withdrawal of PSB made significant difference in dry matter yield when the other components were same. High plant height, number of primary branches per plant, Dry matter accumulation (g), recorded at the combined applications was the resultant effect of balanced crop nutrition. A strong and positive relationship between LAI and dry matter yield helped this fertility treatment to show highest value. Taller plants produced more dry matter because of more opportunity to production and accumulation of photosynthates. These results are in accordance with the findings of Mondal and Sinha (2002); Shukla et al. (2002); Tripathi et al. (2010); Giri et al. (2005).

\subsection{Yield components and yield}

The yield components, viz., number of siliquae plant ${ }^{-1}$, number of seeds per siliqua and test weight (1000 seed weight) showed significant variation due to the effect of different fertility levels used in the nutrient management schedule during the two years of experimentation (Table 1). The highest number of siliquae per plant, number of seeds per siliqua and test weight (1000 seed weight) were obtained from the plot having recommended dose, FYM, Azotobacter and PSB and was closely followed by the treatments consisting of recommended dose along with FYM and Azotobacter and recommended dose along with FYM and PSB. The more number of branches under above treatment 
Table 1: Effect of rapeseed-mustard varieties and nutrient management on plant height, primary branches, dry matter accumulation, yield component, seed and biological yield $\left(\mathrm{kg} \mathrm{ha}^{-1}\right)$

\begin{tabular}{|c|c|c|c|c|c|c|c|c|c|c|}
\hline \multirow[t]{2}{*}{ Treatments } & \multicolumn{2}{|c|}{ Plant height $(\mathrm{cm})$} & \multicolumn{2}{|c|}{ Primary branches } & \multicolumn{3}{|c|}{$\begin{array}{c}\text { Dry matter accumulation }(\mathrm{g}) \\
(2009-10)\end{array}$} & \multicolumn{3}{|c|}{$\begin{array}{c}\text { Dry matter accumulation }(\mathrm{g} \\
(2010-11)\end{array}$} \\
\hline & $2009-$ & $10 \quad 2010-11$ & $11 \quad 2009-10$ & $0 \quad 2010-11$ & $2009-10$ & $2010-11$ & 2009-10 & 2010-11 & $2009-10$ & $2010-11$ \\
\hline \multicolumn{11}{|l|}{ Varieties $(\mathrm{V})$} \\
\hline $\mathrm{V}_{1}-\mathrm{B}-9$ & 103 & 106 & 7.84 & 8.11 & 247.64 & 417.65 & 496.49 & 249.22 & 419.45 & 501.57 \\
\hline $\mathrm{V}_{2}$-RW 85-59(Sarama) & 178 & 180 & 8.63 & 9.01 & 277.22 & 500.03 & 590.58 & 278.94 & 501.69 & 593.89 \\
\hline $\mathrm{V}_{3}-\mathrm{WBB}$ N-1(Kalyan) & 96 & 97 & 6.83 & 7.65 & 226.08 & 341.65 & 428.52 & 227.64 & 343.14 & 434.89 \\
\hline $\mathrm{SEm} \pm$ & 0.40 & 0.185 & 0.038 & 0.028 & 0.19 & 0.51 & 1.20 & 0.27 & 0.55 & 0.47 \\
\hline $\mathrm{CD}(p=0.05)$ & 1.592 & 0.726 & 0.148 & 0.109 & 0.75 & 2.01 & 4.70 & 1.07 & 2.15 & 1.86 \\
\hline \multicolumn{11}{|c|}{ Nutrient management $(\mathrm{F})$} \\
\hline $\mathrm{F}_{1}-\mathrm{RD}$ & 116 & 122 & 7.40 & 7.88 & 240.51 & 386.67 & 452.34 & 241.99 & 388.39 & 457.97 \\
\hline $\mathrm{F}_{2}-\mathrm{RD}+5 \mathrm{t} F Y M$ & 126 & 126 & 7.59 & 8.08 & 246.50 & 411.41 & 496.34 & 248.22 & 413.42 & 496.58 \\
\hline $\mathrm{F}_{3}-\mathrm{RD}+5 \mathrm{t} \mathrm{FYM}+\mathrm{Azo}$ & 128 & 130 & 7.76 & 8.42 & 253.63 & 430.83 & 524.16 & 255.36 & 432.55 & 526.93 \\
\hline $\mathrm{F}_{4}-\mathrm{RD}+5 \mathrm{t} \mathrm{FYM}+\mathrm{PSB}$ & 129 & 129 & 7.94 & 8.31 & 250.08 & 419.54 & 509.34 & 251.66 & 421.17 & 512.68 \\
\hline $\begin{array}{l}\mathrm{F}_{5}-\mathrm{RD}+5 \mathrm{t} \mathrm{FYM}+ \\
\text { Azo+PSB }\end{array}$ & 131 & 132 & 8.14 & 8.58 & 260.84 & 450.41 & 543.80 & 262.44 & 451.60 & 556.44 \\
\hline $\mathrm{SEm} \pm$ & 0.51 & 0.326 & 0.052 & 0.072 & 0.45 & 0.80 & 1.30 & 0.42 & 0.76 & 0.74 \\
\hline $\mathrm{CD}(p=0.05)$ & 1.502 & 0.951 & 0.151 & 0.211 & 1.30 & 2.34 & 3.78 & 1.22 & 2.21 & 2.16 \\
\hline \multirow[t]{2}{*}{ Treatments } & \multicolumn{2}{|c|}{ Test weight (g) } & \multicolumn{2}{|c|}{$\begin{array}{l}\text { No. of siliquae } \\
\text { plant }^{-1}\end{array}$} & \multicolumn{2}{|c|}{$\begin{array}{l}\text { No. of seeds } \\
\text { /siliqua }\end{array}$} & \multicolumn{2}{|c|}{$\begin{array}{c}\text { Seed Yield } \\
\left(\mathrm{Kg} \mathrm{ha}^{-1}\right)\end{array}$} & \multicolumn{2}{|c|}{$\begin{array}{l}\text { Bio. yield } \\
\left(\mathrm{Kg} \mathrm{ha}^{-1}\right)\end{array}$} \\
\hline & $2009-10$ & 2010-11 & $2009-10$ & 2010-11 & $2009-10$ & 2010-11 & $2009-10$ & 2010-11 & $2009-10$ & $2010-11$ \\
\hline \multicolumn{11}{|l|}{ Varieties (V) } \\
\hline $\mathrm{V}_{1}-\mathrm{B}-9$ & 3.97 & 4.14 & 115.92 & 123.73 & 27.14 & 28.51 & 1309 & 1347 & 5283 & 5462 \\
\hline $\begin{array}{l}\mathrm{V}_{2}-\mathrm{RW} 85- \\
59 \text { (Sarama) }\end{array}$ & 3.78 & 3.81 & 179.93 & 182.35 & 14.18 & 14.83 & 1378 & 1438 & 6526 & 6627 \\
\hline $\mathrm{V}_{3}-\mathrm{WBB}$ N-1(Kalyan) & 4.23 & 4.33 & 74.90 & 76.76 & 24.37 & 24.75 & 1222 & 1248 & 4947 & 5214 \\
\hline $\mathrm{SEm} \pm$ & 0.02 & 0.03 & 0.22 & 4.88 & 0.17 & 0.16 & 3 & 5 & 24 & 17 \\
\hline $\mathrm{CD}(p=0.05)$ & 0.07 & 0.11 & 0.84 & 19.14 & 0.65 & 0.64 & 12 & 18 & 96 & 67 \\
\hline \multicolumn{11}{|c|}{ Nutrient management $(\mathrm{F})$} \\
\hline $\mathrm{F}_{1}-\mathrm{RD}$ & 3.77 & 3.87 & 115.38 & 118.57 & 20.04 & 21.24 & 1177 & 1267 & 5306 & 5510 \\
\hline $\mathrm{F}_{2}-\mathrm{RD}+5 \mathrm{t} \mathrm{FYM}$ & 3.97 & 4.06 & 121.21 & 124.56 & 21.28 & 21.92 & 1297 & 1321 & 5504 & 5671 \\
\hline $\mathrm{F}_{3}-\mathrm{RD}+5 \mathrm{t} \mathrm{FYM}+\mathrm{Azo}$ & 4.07 & 4.16 & 127.39 & 131.26 & 22.81 & 23.34 & 1341 & 1373 & 5614 & 5858 \\
\hline $\mathrm{F}_{4}-\mathrm{RD}+5 \mathrm{t} \mathrm{FYM}+\mathrm{PSB}$ & 4.06 & 4.14 & 124.31 & 127.04 & 22.01 & 23.02 & 1316 & 1344 & 5713 & 5810 \\
\hline $\begin{array}{l}\mathrm{F}_{5}-\mathrm{RD}+5 \mathrm{t} \text { FYM }+ \\
\text { Azo+PSB }\end{array}$ & 4.11 & 4.24 & 129.63 & 136.64 & 23.34 & 23.94 & 1384 & 1418 & 5781 & 5990 \\
\hline $\mathrm{SEm} \pm$ & 0.02 & 0.04 & 0.34 & 6.91 & 0.13 & 0.21 & 9 & 6 & 23 & 28 \\
\hline $\mathrm{CD}(p=0.05)$ & 0.06 & 0.11 & 0.98 & 20.16 & 0.37 & 0.62 & 25 & 19 & 66 & 82 \\
\hline
\end{tabular}

may be correlated with the more plant height and dry matter accumulation as a result better nutrient supply to the crop resulting in profuse branching. Profuse branching provided area to develop more number of siliquae in the same treatment. Increase in seeds/siliqua and test weight could be ascribed to the better growth and more photosynthetic accumulation as a result of adequate nutrients availability to the crop.

Seed and biological yield of rapeseed-mustard was markedly influenced as a result of application of plant nutrient from different sources that is in nutrient management manner (Table 1). The significant highest yield was obtained from the plots where rapeseed-mustard received the nutrients in a combination of inorganic, organic and bio-fertilizers, which means the recommended dose of chemical fertilizers were used in that treatment along with FYM, Azotobacter and PSB. It was followed by the application of the recommended dose along 
with FYM, Azotobacter and the recommended dose along with FYM, PSB and these two treatments was found at par. Other fertility level except the plots received only inorganic source of nutrients also showed considerable effect on the seed yield of rapeseed-mustard. Nutrient management treatment devoid of any and organics or bio-fertilizers showed poor effect on productivity of rapeseed-mustard. The interaction of nutrient management and variety significantly influenced the yield and yield components of rapeseed mustard. Maximum yield was recorded with the variety Sarama along with the nutrient management consisting of the recommended dose of chemical fertilizers, FYM, Azotobacter and PSB $\left(\mathrm{V}_{2} \mathrm{~F}_{5}\right)$ and lowest seed yield was recorded with the treatment $\mathrm{V}_{3} \mathrm{~F}_{1}$. One of the important non-symbiotic nitrogen fixing bacteria Azotobacter and phosphate solubulizing bacteria (PSB) beside fixing ambient nitrogen to the soil and solubilize phosphates in the soil, can benefit rapeseed and mustard by producing growth hormones viz., IAA and gibberellins also. Increased seed and biological yield are the resultant effect of better growth and development in this study. With the increment in supply of essential nutrient to rapeseed-mustard, their availability, acquisition, mobilization and influx into the plant tissues increased and thus improved growth attributes, yield components and finally yield. These results are in agreement with the findings of Singh and Sinsinwar (2006); Tripathi et al. (2010); Subhas and Ram (2007); De et al., 2013 and AICRPRM.(2005). Significant increase in yield was found in the variety Sarama followed by Binoy and Kalyan.

\subsection{Nutrient uptake}

The nutrient uptake varied significantly due to different fertility levels (Table 2). The highest nutrient uptake (N, P, K and S) by rapeseed-mustard was noted with the application of the fertility treatment with a combination of the recommended dose of chemical fertilizer along with FYM and bio-fertilizers (Azotobacter and PSB) during both the years. The increased uptake could be ascribed to all nutrients availability to crop that has increased biomass production and thus uptake. Similar results were reported by Mandal and Sinha (2002); Tripathi et al. (2010).

\subsection{Oil content and oil yield}

Oil content (\%) and oil yield of rapeseed-mustard also followed similar trend to that of seed yield (Table 3). Different nutrient management treatments exerted differential effect on oil content (\%) and oil yield of rapeseed-mustard. Maximum oil content (\%) and oil yield of rapeseed-mustard was recorded from the plot that received FYM, Azotobacter, PSB and chemical fertilizer. It was closely followed by the fertility treatments consisting of the recommended dose, FYM and Azotobacter; recommended dose, FYM and PSB; and these two treatments were at par with each other. The nutrient management practice devoid of any organics showed poor oil content (\%) and oil yield of rapeseed-mustard. It was observed that the varieties used in this study had significant effect on oil content (\%) of rapeseed and mustard. This trend was found in both the years of the study. Here the variety Binoy exerted maximum oil content (\%) which was followed by the variety Sarama. It was also observed that both the varieties showed better effect on oil content (\%) over the variety Kalyan. Increase in biological yield could be ascribed to better growth and more photosynthates accumulation as a result of adequate nutrients availability to the crop. It was observed that the varieties used in this study had significant effect on oil yield $\left(\mathrm{q} \mathrm{ha}^{-1}\right)$ of rapeseed and mustard. This trend was found in both the years

\begin{tabular}{|c|c|c|c|c|c|c|c|c|}
\hline \multirow[t]{2}{*}{ Treatments } & \multicolumn{2}{|c|}{ Avail. N $\left(\mathrm{kg} \mathrm{ha}^{-1}\right)$} & \multicolumn{2}{|c|}{ Avail. $\mathrm{P}\left(\mathrm{kg} \mathrm{ha}^{-1}\right)$} & \multicolumn{2}{|c|}{ Avail. K $\left(\mathrm{kg} \mathrm{ha}^{-1}\right)$} & \multicolumn{2}{|c|}{ Avail. S $\left(\mathrm{kg} \mathrm{ha}^{-1}\right)$} \\
\hline & 09-10 & $10-11$ & $09-10$ & $10-11$ & $09-10$ & $10-11$ & $09-10$ & $10-11$ \\
\hline \multicolumn{9}{|l|}{ Varietties $(\mathrm{V})$} \\
\hline $\mathrm{V}_{1}-\mathrm{B}-9$ & 91.07 & 92.27 & 30.83 & 31.21 & 105.27 & 106.00 & 10.56 & 10.65 \\
\hline $\mathrm{V}_{2}-\mathrm{RW} 85-59$ & 95.13 & 96.60 & 32.40 & 32.63 & 108.67 & 109.16 & 11.19 & 11.38 \\
\hline $\mathrm{V}_{3}$-WBB N-1 & 85.13 & 86.13 & 29.64 & 30.25 & 102.19 & 102.60 & 10.13 & 10.31 \\
\hline $\mathrm{SEm} \pm$ & 0.17 & 0.16 & 0.13 & 0.12 & 0.09 & 0.15 & 0.03 & 0.03 \\
\hline $\mathrm{CD}(p=0.05)$ & 0.66 & 0.62 & 0.52 & 0.47 & 0.35 & 0.59 & 0.12 & 0.11 \\
\hline \multicolumn{9}{|l|}{ Nutrient management $(\mathrm{F})$} \\
\hline $\mathrm{F}_{1}-\mathrm{RD}$ & 83.33 & 84.50 & 26.08 & 26.48 & 101.49 & 102.07 & 10.17 & 10.36 \\
\hline $\mathrm{F}_{2}-\mathrm{RD}+5 \mathrm{t} F Y M$ & 90.78 & 91.96 & 30.51 & 31.07 & 105.84 & 106.28 & 10.60 & 10.76 \\
\hline $\mathrm{F}_{3}-\mathrm{RD}+5 \mathrm{t} \mathrm{FYM}+\mathrm{Azo}$ & 92.89 & 94.32 & 30.76 & 31.13 & 106.49 & 106.97 & 10.76 & 10.90 \\
\hline $\mathrm{F}_{4}-\mathrm{RD}+5 \mathrm{t} \mathrm{FYM}+\mathrm{PSB}$ & 91.11 & 92.20 & 33.64 & 34.08 & 105.50 & 106.08 & 10.66 & 10.81 \\
\hline $\mathrm{F}_{5}-\mathrm{RD}+5 \mathrm{t} \mathrm{FYM}+\mathrm{Azo}+\mathrm{PSB}$ & 94.11 & 95.36 & 33.80 & 34.07 & 107.54 & 108.21 & 10.96 & 11.07 \\
\hline $\mathrm{SEm} \pm$ & 0.23 & 0.33 & 0.14 & 0.15 & 0.13 & 0.16 & 0.04 & 0.03 \\
\hline $\mathrm{CD}(p=0.05)$ & 0.68 & 0.98 & 0.40 & 0.45 & 0.39 & 0.48 & 0.11 & 0.08 \\
\hline
\end{tabular}




\begin{tabular}{|c|c|c|c|c|c|c|c|c|c|c|c|}
\hline \multirow[t]{2}{*}{ Treatments } & \multicolumn{2}{|c|}{$\begin{array}{l}\text { Oil content } \\
(\%)\end{array}$} & \multicolumn{2}{|c|}{$\begin{array}{l}\text { Oil yield } \\
\left(\mathrm{q} \mathrm{ha}^{-1}\right)\end{array}$} & \multirow{2}{*}{$\begin{array}{c}\text { Cost of } \\
\text { Cultiva- } \\
\text { tion } \\
\left(₹ \mathrm{ha}^{-1}\right)\end{array}$} & \multicolumn{2}{|c|}{ Gross return $(₹)$} & \multicolumn{2}{|c|}{ Net return $(₹)$} & \multicolumn{2}{|c|}{ Benefit:Cost } \\
\hline & $\begin{array}{c}2009- \\
10\end{array}$ & $\begin{array}{c}2010- \\
11\end{array}$ & $\begin{array}{c}2009- \\
10\end{array}$ & $\begin{array}{c}2010- \\
11\end{array}$ & & $\begin{array}{c}2009- \\
10\end{array}$ & $\begin{array}{c}2010- \\
11\end{array}$ & $\begin{array}{c}2009- \\
10\end{array}$ & $\begin{array}{c}2010- \\
11\end{array}$ & $\begin{array}{c}2009- \\
10\end{array}$ & $\begin{array}{c}2010- \\
11\end{array}$ \\
\hline \multicolumn{12}{|l|}{ Varieties (V) } \\
\hline $\mathrm{V}_{1}-\mathrm{B}-9$ & 40.10 & 39.82 & 525 & 539 & 13469 & 34027.0 & 35195.3 & 20558.1 & 21726.3 & 2.52 & 2.62 \\
\hline $\mathrm{V}_{2}$-RW 85-59 & 38.21 & 38.11 & 527 & 549 & 13469 & 35828.0 & 37396.6 & 22359.0 & 23927.7 & 2.66 & 2.78 \\
\hline $\mathrm{V}_{3}-\mathrm{WBB} \mathrm{N}-1$ & 37.13 & 37.75 & 454 & 471 & 13469 & 31772.0 & 32449.7 & 18303.0 & 18980.7 & 2.36 & 2.41 \\
\hline $\operatorname{SEm} \pm$ & 0.02 & 0.14 & 04 & 06 & - & 239.3 & 281.1 & 239.3 & 281.1 & 0.02 & 0.02 \\
\hline $\mathrm{CD}(p=0.05)$ & 0.09 & 0.56 & 15 & 23 & - & 939.4 & 1103.40 & 939.4 & 1103.4 & 0.07 & 0.08 \\
\hline \multicolumn{12}{|l|}{ Nutrient management $(\mathrm{F})$} \\
\hline $\mathrm{F}_{1}: \mathrm{RD}$ & 37.98 & 37.88 & 447 & 480 & 12189 & 29863.0 & 30472.5 & 18404.3 & 20758.8 & 2.45 & 2.50 \\
\hline $\mathrm{F}_{2}: \mathrm{RD}+5 \mathrm{t} F Y M$ & 38.28 & 38.26 & 497 & 505 & 13689 & 33713.3 & 34337.3 & 20024.3 & 20648.3 & 2.46 & 2.51 \\
\hline $\mathrm{F}_{3}: \mathrm{RD}+5 \mathrm{t} \mathrm{FYM}+\mathrm{Azo}$ & 38.59 & 38.76 & 518 & 532 & 13789 & 34868.8 & 35692.2 & 21079.9 & 21903.2 & 2.53 & 2.59 \\
\hline $\mathrm{F}_{4}: \mathrm{RD}+5 \mathrm{t} F Y M+\mathrm{PSB}$ & 38.49 & 38.69 & 509 & 520 & 13789 & 34207.3 & 34941.1 & 20418.3 & 21152.1 & 2.48 & 2.53 \\
\hline $\mathrm{F}_{5}: \mathrm{RD}+5 \mathrm{t} \mathrm{FYM}+\mathrm{Azo}+\mathrm{PSB}$ & 38.88 & 39.22 & 538 & 561 & 13889 & 35995.5 & 37151.1 & 22106.6 & 23262.1 & 2.59 & 2.67 \\
\hline $\mathrm{SEm} \pm$ & 0.04 & 0.12 & 05 & 07 & - & 348.7 & 470.0 & 348.7 & 470.1 & 0.03 & 0.03 \\
\hline $\mathrm{CD}(p=0.05)$ & 0.11 & 0.34 & 15 & 22 & - & 1017.7 & 1371.8 & 1017.7 & 1371.8 & 0.08 & 0.10 \\
\hline
\end{tabular}

Land preparation@ @ 1900 ha $^{-1}$; Cost of seed @ ₹ $25 \mathrm{~kg}^{-1}$; 3 Irrigations@ ₹ 620 ha $^{-1}$ irrigation; 47 Labours @ ₹ 120 labour; Urea@ ₹ $5.30 \mathrm{~kg}^{-1}$; SSP @ ₹ $5.20 \mathrm{~kg}^{-1}$; MOP@ ₹ $5.10 \mathrm{~kg}^{-1}$; FYM @ ₹ $300 \mathrm{t}^{-1}$; Azotobacter @ ₹ $100400 \mathrm{~g}^{-1}$ packet; PSB @ ₹ $100400 \mathrm{~g} \mathrm{~g}^{-1}$ packet $^{-1}$; Sale rate of Rapeseed-mustard product @ ₹ $26 \mathrm{~kg}^{-1}$

of the study. Here the variety Sarama exerted maximum oil yield $\left(\mathrm{q} \mathrm{ha}^{-1}\right)$ which was at par with the variety Binoy. It was also observed that both the varieties showed better effect on oil yield $\left(\mathrm{q} \mathrm{ha}^{-1}\right)$ over the variety Kalyan.

\subsection{Economics}

The economics of integrated nutrient management on rapeseedmustard showed that during both the years of the study, the significantly higher gross return, net returns and benefit-cost ratio were obtained from the treatments where nutrients from different sources that is from chemical along with either organic matter or organic matter and bio-fertilizers were applied together (Table 3). The highest gross return, net returns and benefit-cost ratio during the two years of the experimentation were recorded from the rapeseed-mustard crop raised with the application of recommended dose of chemical fertilizers, FYM, Azotobacter and PSB together.

\section{Conclusion}

Application of nutrient management treatments consisting of the recommended dose, FYM and bio-fertilizers (Azotobacter and PSB) with either of the variety Sarama or Binoy are best for higher productivity and profitability in cultivation of rapeseedmustard in Gangetic alluvial zone of West Bengal.

\section{References}

Anonymous, 2015. Economic Survey, 2014-15: A25-A26.
Anonymous, 2005. Annual Progress Report of All India Coordinated Research Project on Rapeseed-Mustard. A1-28.

Anonymous, 2014. Annual Progress Report of All India Coordinated Research Project on Rapeseed-Mustard 2014-15, 9-11.

Anjum, N.A, Gill, S.S, Umar, S., Ahmed, I., Durate, A.C., Pereira, E., 2012. Improving Growth and Productivity of Oleiferous Brassicas under Changing Environment: Significance of Nitrogen and Sulphur Nutrition and Underlying Mechanisms.The Scientific World Journal, Article ID657808, 12 pages. doi:10.1100/2012/657808

Cardole, M., Mazzoncini, M., Menni, S., 2003. Brassica carinata as an alternative oil crop for the production of biodiesel in Italy: agronomic evaluation, fuel production by transesterification and characterization. Biomass and Bioenergy 25(6), 623-636.

De, B., Sinha, A.C., 2011. International Nutritional Management on Rapeseed (Yellow sarson) Lambert Academic Publisher, Germany.

De, B., Sinha, A.C., Patra, P.S., 2009.Effect of organic and inorganic sources of nutrient on rapeseed (Brassica campestris L.) under terai region. Journal of Crop and Weed 5, 281-284.

De, B., Sinha, B., Ghosh M., Sinha A.C., 2013. Seed Yield Variation of Rapeseed (Brassica campestris) by Integrated Nutrient Management Practices under 
Rain-fed Condition of Terai Region in West Bengal, India. International Journal of Bio-resource and Stress Management 4(2), 154-160.

De, B., Das, B., Das, B., Sinha, A.C., 2014. Effect of integrated nutrient management on yield, nutrient uptake and economics of rapeseed (Brassica campestris var. yellow sarson) in terai region of West Bengal. Journal of Crop and Weed 10(1), 69-72.

Giri, P.R., Khawale, V.S., Pawar, W.S., Sonawale, A.B., 2005. Effect of phosphorus and sulphur application on growth and yield of Brassica juncea. Journal of Soils and Crops 15(2), 448-451.

Maiti, S., Patra,T., Ojha, S.,2005. Integrated nutrient management on the productivity of Brassica spp. and its residual effect on the succeeding green gram crop. Journal of Crop and Weed 1(1), 1-4.

Mohiuddin, M., Paul, A.K., Sutradhar, G.N.C., Bhuiyan, M.S.I., Zubair, H.M., 2011. Response of nitrogen and sulphur fertilizers on yield, yield components and protein content of oilseed mustard (Brassica spp). International Journal of Bio-resource and Stress Management 2(1), 93-99.

Mondal, K.G., Sinha, A.C., 2002. Effect of integrated nutrient management on growth, yield, oil content and nutrient uptake of Indian mustard (Brassica juncea) in foothills soils of eastern India. Indian Journal of Agronomy 47(1), 109-113.
Prasad, R., Sharma, S.N., Singh, S., Lakshaman, R., 1992. Agronomic Practice for increasing nutrient use efficiency and sustained crop production. In proceedings of the National Seminar on Resource Management for sustainable Production, New Delhi, India, February.

Shekhawat, K., Rathore, S.S., Premi, O.P., Kandpal, B.K., Chauhan, J.S., 2012. Advances in Agronomic Management of Indian Mustard (Brassica juncea (L.) Czernj. Cosson): An Overview. International Journal of Agronomy 2012, Article ID 408284. http://dx.doi. org/10.1155/2012/408284.

Shukla, R.K., Kumar, A., Mahapatra, B.S., Kandpal, B., 2002. Integrated nutrient management practices in relation to morphological and physiological determinants of seed yield in Indian mustard (Brassica juncea). Indian Journal of Agricultural Sciences 72(11), 670-672.

Singh, R. Sinsinwar, B.S., 2006. Effect of integrated nutrient management on growth, yield, oil content and nutrient uptake of Indian mustard. (Brassica juncea). Indian Journal of Agricultural Sciences 76(5), 322-324.

Subhash, C., Ram, D., 2007. Effect of integrated nutrient management on yield and nutrient use efficiency in mustard. Indian Journal of Fertilizer 3, 51-54.

Tripathi, M.K., Chaturvedi, S., Shukla, D.K., Mahapatra. 2010. Yield performance and quality in Indian mustard (Brassica juncea) as affected by integrated nutrient management. Indian Journal of Agronomy 55 (2), 138-142. 